\title{
BAZSA GYÖRGY
}

\section{METSZETEK FELSŐOKTATÁSUNK KÖZELMÚLTJÁBÓL}

\section{(Debrecen, Debreceni Egyetemi Kiadó, 2014, 134 lap)}

Bazsa György, a Debreceni Egyetem emeritus professzora, a korábbi Kossuth Lajos Tudományegyetemnek előbb dékánhelyettese, dékánja, majd 1995-99 között időben utolsó rektora nemcsak egyetemi vezetőként, hanem félévszázadon át oktatóként vett részt a felsőoktatásban. Részese és - a fenti egyetemi funkcióin túl - számos országos döntéshozó szervezet tagjaként/elnökeként alakítója is volt a felsőoktatás elmúlt évtizedeiben zajló eseményeknek: az oktatási reformoknak, szervezeti átalakításoknak, a tudomány és oktatás közötti kapcsolatok alakulásának, a felsőoktatási törvények létrehozásának és ismételt módosításoknak, ezért így visszatekintve hitelesen ismerteti, kritikusan értékeli azok eredményeit és fogyatékosságait. Objektív, konkrét adatokkal alátámasztott, de szubjektív megjegyzésekkel kiegészített visszaemlékezése tanulságul szolgál napjaink felsőoktatása problémáinak, megoldandó kérdéseinek felismerésében, és irányt mutat a jövő feladatainak meghatározásához.

Számomra, mint a Debreceni Orvostudományi Egyetem, majd az integrációt követően Debreceni Egyetem oktatója számára talán legizgalmasabb volt a könyv első fejezete, amelyben a szerző a Kossuth Lajos Tudományegyetem 1949-99 közötti 50 évét, a nehézségek és korlátok ellenére „egy folyamatosan fejlödo", növekvö és erösödo", gazdagodó és megújuló, az egyetemes tudományt és a magyar társadalmat szolgáló nagy egyetemi egység történetét" mutatja be. Az 1949-ben megcsonkított Debreceni Egyetem, 1952-től Kossuth Lajos Tudományegyetem alapító kara, a Természettudományi Kar történetén keresztül ismerhetjük meg a félévszázad debreceni felsőoktatásának jellemzőit, amely 2000-ben az integrációval újjászülető Debreceni Egyetemnek is meghatározó kara lett. Az integráció, a Debreceni Universitas létrejöttét megelőző öt évtized keresztmetszete túlmutat a helyi egyetemi oktatás jellemzőin: az infrastruktúra fejlesztésére, az intézetek létrehozására/megszűnésére, új karok alapítására, az oktatói kar és hallgatói létszám, a finanszírozás alakulására vonatkozó adatok ismertetésével, a Kar kiemelkedő egyéniségeinek, az első minősített professzoroknak az említésével, a kialakuló nemzetközi kapcsolatok és a kiemelkedő hazai tudományos eredmények jelentőségének hangsúlyozásával, a sikerek és nehézségek bemutatásával általános, a kor hazai felsőoktatásának egészére érvényes képet kapunk.

A rendszerváltás a kari müködésbe is új, demokratikus elemeket hozott, s ez az 1993-as felsőoktatási törvényben is megfogalmazódott: erősebb egyetemi autonómia, 
megváltozott felvételi pontozási rendszer, nagyobb hallgatói képviselet, a $\mathrm{PhD}$ doktori fokozat odaítélésének joga az egyetemeken. A leírtak meggyőzik az olvasót arról, hogy az ezredfordulóra a Kossuth-egyetem oktatógárdája mind a kutatásban, mind az oktatásban megfelelt a kor elvárásainak, és a Kossuth Lajos Tudományegyetem a hazai felsőoktatás kiemelkedő eredményeket produkáló szakmai bázisa volt.

Az integráció előtti utolsó KLTE tanácsülésen elhangzott beszédből megismerhetjük az integráció megvalósulásának körülményeit. Az integráció előkészítésében az 1991-ben létrehozott Debreceni Universitas Egyesülés játszott szerepet, amelynek jogi kereteit csak az 1993-as felsőoktatási törvény 1996-os módosítása teremtette meg, s 2000. január 1-jén létrejött az integrált Debreceni Egyetem, az ország legszélesebb szakmai spektrumú egyeteme. A szerző, a KLTE utolsó rektora, az integráció feltétlen híve és harcosa a nehézségek és kényszerủ megalkuvások ellenére hitet tesz amellett, hogy a Debreceni Egyetem "súlya és erössége a valódi integrált egyetemi létben lehet és lesz is". A biztosítékot abban látja, hogy a csatlakozó karok és egységek a minőséget és a szellemiséget viszik az új intézménybe: egy sokkarú, multidiszciplináris, oktatásban és kutatásban együttműködést akaró, ebben már tapasztalattal bíró intézményről van szó, amelynek tagjai képesek együtt gondolkodni, az érdekeket nem csak ütköztetni, de egyeztetni is.

A könyv következő fejezeteiben a felsőoktatás irányító és döntéshozó testületeiben: a Magyar Rektori Konferencia (MRK), a Felsőoktatási és Tudományos Tanács (FTT), Országos Doktori és Habilitációs Tanács (ODHT), a Magyar Felsőoktatási Akkreditációs Bizottság $(\mathrm{MAB})$ testületeiben végzett munkát foglalja össze. Történelmi távlatokban ismerteti az egyes testületek létrehozásának körülményeit, feladatukat, tevékenységüket, hitelesen mutatja be a lehetőségeket és a korlátozó tényezőket, levonja a jövőre vonatkozó, sok tekintetben a mára is érvényes tanulságokat. Motivációját a kerek évfordulókkal összefüggő értékelések mellett az új felsőoktatási törvény, a forráskivonás okozta körülmények, az oktatói és hallgatói létszám csökkenése jelentették, amelyek a „hogyan tovább” kérdését, a felsőoktatás jövőjének gondját vetették fel.

A Magyar Rektori Konferencia 25 éves jubileumi ülésén tartott beszédében a szerző hangsúlyozza, hogy mủködésük a „kimüvelt emberfök sokaságáért” célt szolgálja. Megismerkedhetünk a testület felsőoktatás átalakításában játszott szerepével, a számadatokkal alátámasztott, nem előnyös tendenciákkal szembeni állásfoglalásaikkal. A negyedszázad alatt változott a jogi és működési környezet, s így változott a szervezet célja, funkciója, módosultak feladatai és lehetőségei. A rendszerváltás magával hozta az új út keresésének idejét: „A megújulás vágya és szüksége az élet minden területén mutatkozik”mondta az MRK elnöke 1989-ben az Országos Egyetemi Fórumon. Az új út keresésében a fejlett és demokratikus „Nyugat” (Citizens Democracy Corps) sokféle formában segített: az európai mintát követve átfogó terv készítését, a célok és azok fontossági sorrendjének meghatározását, az egyetemi autonómia biztosítását, a rektorok és dékánok egyetemi és kari tanácsok általi választását javasolta. Az MRK progresszív vezetői javas- 
lataikat „A magyar felsőoktatás fejlesztése 2000-ig” című ún. „zöld könyvben” foglalták össze (1992). Ma is érvényes meghatározásuk a következő: „A felsőoktatás szinvonala, fejlödése meghatározó feltétele a magyar társadalom és gazdaság átalakulásának, jövöbeli perspektivájának." A leírtak "fontos és világos vezérfonalat jelentettek... mindenki tudta, merre van az új ut". A következő másfél évtizedet a szerző gyors expanzióval, három törvény megszületésével (Ftv. 1995, 2005, Nftv. 2011 - a szerző a három törvényt külön értékeli), változó finanszírozással járó „mozgalmas” negyedszázadként jellemzi. A képzési rendszerben a háromszintű bolognai felmenő rendszer került bevezetésre (Bologna Declaration, 1999), a PhD képzés és fokozatszerzés joga az egyetemek kezébe került, létrejött és jól működött az európai felsőoktatási minőségbiztosítás közös felfogású rendszere. Az utóbbi két évben a felsőoktatás átalakítására irányuló törekvések alapját a Széll Kálmán tervben (2011) megfogalmazott állítás jelentette: „[...] felsőoktatásunk értéket nem termel, összességében csak növeli az államadósságot!!!”. „[...] túlburjánzó szakkinálat, fenntarthatatlan párhuzamosságok, több helyen minöségében megkérdöjelezhetö teljesitmény... ” fogalmazódtak meg a kifogások. A MRK határozottan felsorolja a felsőoktatás közeljövőjét is veszélyeztető intézkedések ellenérveit, figyelmeztetve a fiatalok ország-elhagyására, a családok anyagi terheit növelő intézkedésekre, a forráskivonás nemzetközi trendekkel ellentétes voltára. A HÖK szerint mély válságban van a magyar felsőoktatás. A folyamat tart, a felsőoktatás elkötelezett képviselői hallatják hangjukat. A „hogyan” a könyvben megtalálható. A felsőoktatás jelentőségének felismerése, érdekérvényesítése, az azt támogató kormánystratégia nélkül a hazai felsőoktatás kudarca fenyeget. Ennek elkerülése az egész magyar társadalom érdeke.

A Felsőoktatási és Tudományos Tanács tagjaként a könyv szerzője aktív szerepet vállalt a 2004-es felsőoktatási törvénytervezet véleményezésében. A törvénytervezet kormányhoz benyújtott végleges formája az általuk javasolt korrekciók figyelembevételével megszületett konszenzus eredménye.

Az Országos Doktori és Habilitációs Tanács a doktori képzés és fokozatszerzés rendszerváltozást követő sikeres átszervezésében játszott szerepet: létrejöttek a hároméves szervezett képzést biztosító doktori iskolák. A tudományos utánpótlás szervezett képzésében és a tudományos fokozat odaítélésében az egyetemeknek meghatározó szerepük van, $s$ az Akadémia részt vesz a tudományos tevékenység értékelésében. A minőségi és tartalmi kérdésekben való állásfoglalás az Akkreditációs Bizottság feladata. A „Magyar Tudományos Akadémia doktora” címet az Akadémia saját hatáskörében ítéli oda.

A Magyar Felsőoktatási Akkreditációs Bizottság fél évtizeden keresztüli elnökeként kifejti a minőségüggyel és az akkreditációval kapcsolatos kérdéskört, amelynek hazai bevezetését a felsőoktatás jó színvonalának biztosításához hozzájáruló, jelentős tényezőnek tartott. Kritikusan állapítja meg, hogy a 2011. évi CCIV. törvény hatályba lépésével a felsőoktatás szereplőinek, intézményeinek korábbi tevékenysége, működésük jogszabályi keretei és anyagi lehetőségei jelentősen korlátozódtak, és megfogalmazódik a MAB függetlenségét hiányoló véleménye is. A MAB a jövőben is legyen "független 
országos szakérto" testület”. Az „Uj utak” cím alatt az európai út, az európai sztenderdek és irányelvek követését tartja szükségesnek.

Meggyőződésem, hogy az összeállítás - a szerző céljának megfelelően - segítséget nyújt a magyar felsőoktatás európai értékrendjének és egyensúlyának visszarendezéséhez és megtartásához. A könyvben bemutatott helyzetelemzéseket és megfogalmazott gondolatokat minden felsőoktatásban érintett szakembernek érdemes áttanulmányozni és a döntéshozatal során figyelembe venni.

Oláh Éva 